\title{
Exantemas maculopapulares en COVID-19: experiencia de 14 casos
}

\section{Maculopapular rashes in COVID-19: experience of 14 cases}

\author{
Gilberto Adame Miranda, ${ }^{*}$ Jorge Flores Ochoa, \\ Mavi Patricia López Sroor,\$ Heidi Muñoz Hink," \\ Romeo Velázquez Manzo, "I Adriana Miranda Gómez, ** \\ María Graciela Guzmán Perera, ${ }^{\neq \neq}$ \\ Julio César Salas Alanís $\$$
}

Citar como: Adame MG, Flores OJ, López SMP, Muñoz HH, Velázquez MR, Miranda GA et al. Exantemas maculopapulares en COVID-19: experiencia de 14 casos. Acta Med Grupo Angeles. 2021; 19 (s1): s48-s57. https://dx.doi.org/10.35366/101028

\section{Resumen}

El exantema maculopapular es la manifestación más frecuente relacionada con la enfermedad COVID-19, lamentablemente los exantemas han sido descritos de tantas maneras que la incidencia exacta la desconocemos. La mayoría de los autores incluyen en este rubro los exantemas morbiliformes, los maculopapulares, los eritematoescamosos, los pitiriasis rosada-like y los eritema polimorfo like. En la última revisión de la literatura hasta julio de 2021 elaborada por Li y colaboradores el exantema eritematoso maculopapular es la manifestación más frecuente de COVID-19 con un 38.4\%. En un estudio de vigilancia de pruebas positivas en China con 678 pacientes, el exantema eritematoso ocupó $70 \%$ de las lesiones cutáneas. El promedio de edad es de 61.1 años con similar afectación en ambos sexos. Las erupciones maculopapulares y morbiliformes pueden ser localizados o diseminados, simétricos o confluentes. Se inician en el tronco y diseminan a las extremidades. Aún no comprendemos completamente su fisiopatología, si todos ellos están asociados directamente al SARS-CoV-2, si algunos son reacciones a medicamentos o si se deben a reactivación de otros virus.

Palabras clave: Eritema, exantema, mácula, pápula, morbiliforme.

\section{Abstract}

The maculopapular rash is the most frequent manifestation related to the COVID-19 disease, unfortunately the rashes have been described in so many ways that the exact incidence is unknown. Most of the authors include morbilliform, maculopapular, erythematous-squamous, pityriasis rosea-like and polymorphous like erythema under this heading. In the last revision of the literature up to July of this year elaborated by $\mathrm{Li}$, et al, the erythematous maculopapular exanthema is the most frequent manifestation of COVID-19 with $38.4 \%$ of the cases. In a surveillance study of positive tests in China, with 678 patients, erythematous rash accounted for $70 \%$ of skin lesions. The average age was 61.1 years, with similar involvement in both sexes. Maculopapular and morbilliform eruptions can be localized or disseminated, symmetrical or confluent. They start in the trunk and spread to the extremities. We still do not fully understand their pathophysiology, if all of them are directly associated with SARS-CoV-2, if some are reactions to drugs or if they are due to reactivation of other viruses.

Keywords: Erythema, exanthema, macula, papule, morbilliform.
* Dermatólogo en práctica privada. Expresidente de la Academia Mexicana de Dermatología y de la Fundación Mexicana para la Dermatología. Actual Presidente del Colmexiderma. México.

₹ Médico General. Medicina privada. México.

§ Dermatóloga, Hospital Ángeles Chihuahua (Colmexiderma). México.

* Dermatóloga en práctica privada (Colmexiderma). México.

I| Otorrinolaringólogo, Hospital Ángeles Pedregal. México.

** Dermatóloga, Hospital Ángeles Pedregal (Colmexiderma). México.

\#キ Dermatóloga, Hospital Ángeles Pedregal, Expresidenta de la Academia Mexicana de Dermatología, la Fundación Mexicana para la Dermatología y del Colmexiderma.
$\$ \S$ Dermatólogo privado en Monterrey, Nuevo León. Profesor de la Facultad de Medicina del Instituto Tecnológico de Monterrey (Colmexiderma).

Correspondencia:

María Graciela Guzmán Perera

Correo electrónico: graceguzman07@gmail.com

www.medigraphic.com/actamedica

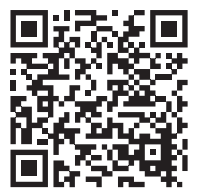




\section{INTRODUCCIÓN}

Las erupciones morbiliformes son exantemas caracterizadas por máculas edematosas que dejan en su interior algunas lagunas de piel normal, pueden ser generalizadas $(80 \%)$, simétricas $(55 \%)$ confluentes $(54 \%)$. Se pueden iniciar en el tronco y se extienden en forma centrífuga. Algunas pueden asociarse con enantemas, manchas eritematosas o purpúricas en el paladar blando. El síntoma principal es el prurito y pueden durar en promedio unos cinco días. ${ }^{1-3}$ Este tipo de exantema se parece al del sarampión o la rubeola sin las características propias de esas enfermedades. Se pueden asociar con medicamentos como el tocilizumab.

Los exantemas papulomaculares son aquellos que presentan pápulas sobre una base eritematosa, predominan en las mujeres y más de la mitad de los casos tienen un importante prurito, pueden durar entre 11 y 12 días. La mayoría son generalizados y simétricos donde se inician las máculas ligeramente descamativas. Se presentan con frecuencia asociados con la ingesta de medicamentos como la hidroxicloroquina, el lopinavir/ritonavir y la azitromicina.

Los cuadros pitiriasis rosada like se han asociado más al acetaminofén y a los antipalúdicos de síntesis. Hay erupciones localizadas que se parecen al eritema elevatum diutinum y que se presentan con el acetaminofén. ${ }^{3}$

La aparición de estos exantemas puede ser causada por los efectos citopáticos del virus cuando se presentan antes de los síntomas y durante la enfermedad. Los exantemas tardíos están más relacionados con la ingesta de medicamentos, probablemente a la tormenta inflamatoria que produce complejos inmunes y metabolitos de los medicamentos que recibió. ${ }^{4}$
Alrededor de 50\% pueden ser negativos a la PCR, dependiendo del momento en el que éstos se presentan durante la enfermedad. La mayor parte de los enfermos tienen elevada la proteína $\mathrm{C}$ reactiva ultrasensible. ${ }^{3}$

Los mecanismos productores de los exantemas no están bien comprendidos. Las partículas del virus presentes en la sangre que circula en los vasos cutáneos puede causar endotelitis, dilatación de los vasos y edema. ${ }^{5}$ En la fase exantemática aguda, la biopsia sólo muestra los datos antes descritos. Después, las paredes de los vasos se infiltran de linfocitos y neutrófilos. En la fase papular se observa ligera exocitosis con mínimos cambios vacuolares en la unión dermoepidérmica, edema de la dermis papilar y ocasionalmente trombosis.

En la etapa dos el edema y la infiltración inflamatoria perivascular son muy intensas, se incrementa el número de eosinófilos y hay más extravasación de eritrocitos. Infiltrado denso periglandular y perivascular. Cuadro histológico similar a los sabañones. ${ }^{6}$

En las fases tardías, el cuadro histológico es similar al eritema polimorfo, hay numerosos eosinófilos, casi no hay dermatitis de interfaz y queratinocitos necróticos. ${ }^{6}$ En el nivel tres se observan mucho más intensos los cambios antes mencionados, además de trombos de vasos pequeños y medianos, CD8+ epidermotrópicos.

La linfopenia puede además favorecer la activación de virus latentes de la familia de herpes humano (HHV) y Epstein-Barr (EBV), los metabolitos de los medicamentos funcionan como antígenos que, aunados a la tormenta inmunológica de la virosis misma, se encargan de causar daños más severos.

En esta comunicación los clasificamos como tempranos, concomitantes y tardíos a la virosis.

Expondremos en capítulos separados los similares a la pitiriasis rosada y los eritema polimorfo like.

\section{Figura 1:}

Exantema maculopapular diseminado en tórax y brazos. Sin otro signo clínico. PCR+ (prueba de reacción en cadena de la polimerasa positiva).
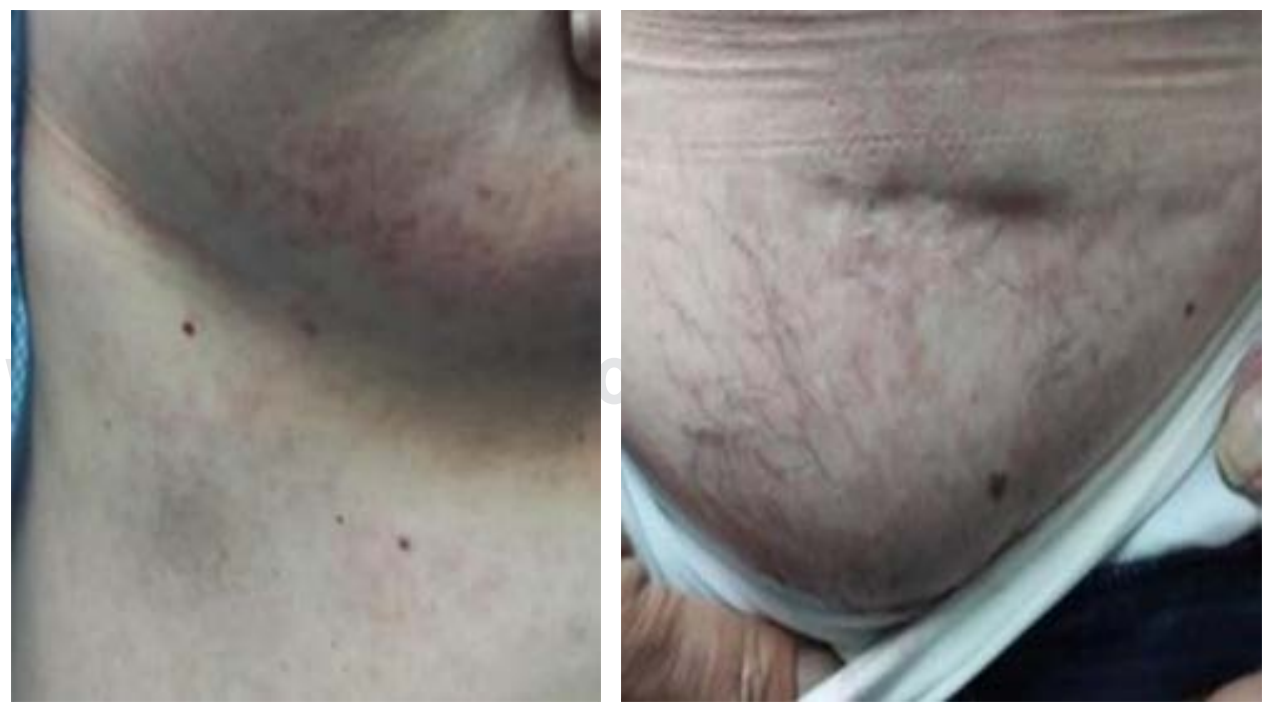

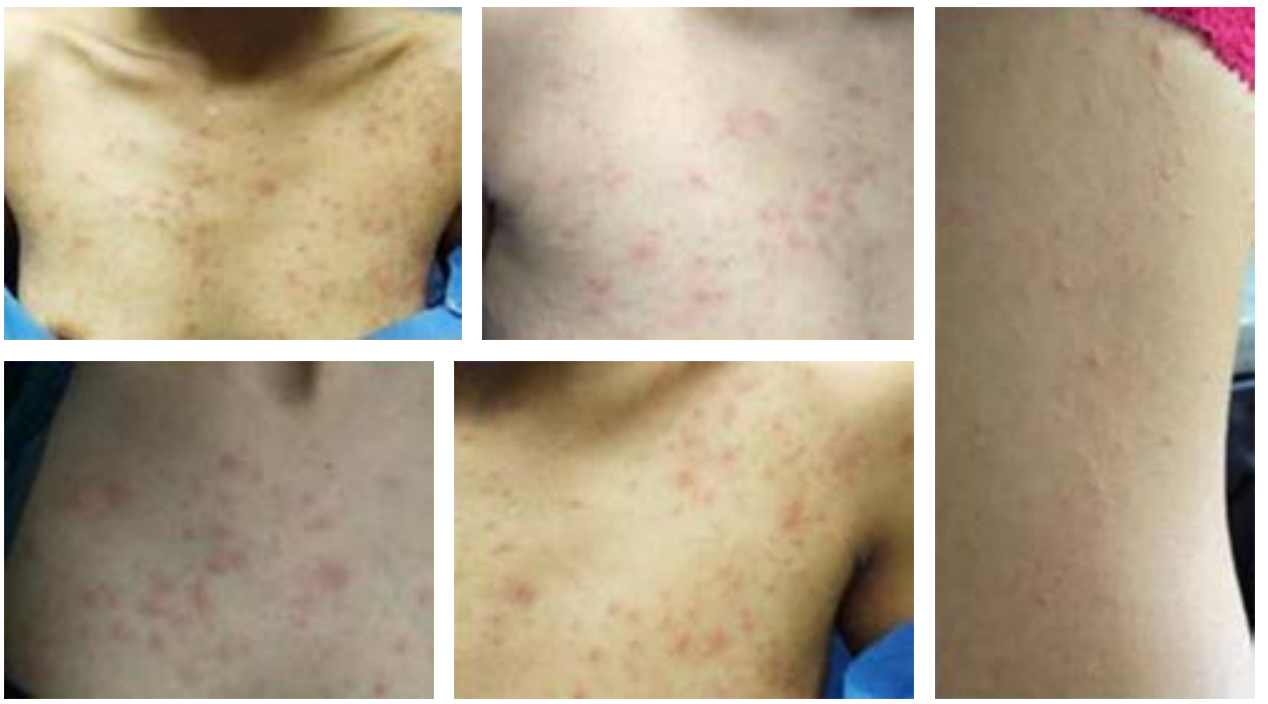

Exantema maculopapular con afección de tórax.
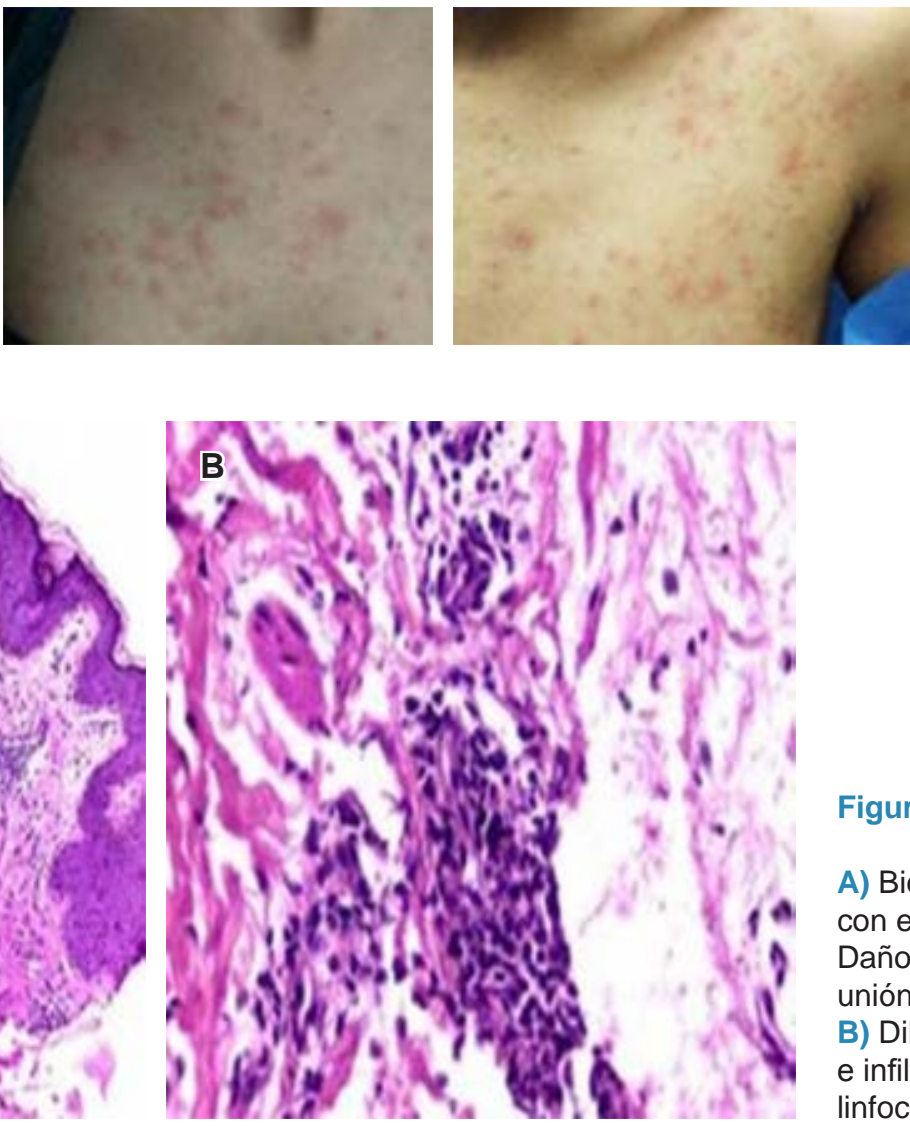

Figura 3:

A) Biopsia de piel delgada con epidermis normal. Daño de interfaz en la unión dermoepidérmica. B) Dilatación vascular e infiltrado inflamatorio linfocítico y neutrofílico.

\section{EXANTEMAS MACULOPAPULARES \\ QUE PRECEDEN AL COVID}

Caso 1

Mujer de 50 años, vecina de la Ciudad de México. Padeció hepatitis viral a los 9 años, hipertensión arterial sistémica de 10 años de evolución controlada con telmisartán/ amliodipino, trastornos funcionales del colon tratados con trimebutina/simeticona. Enfermedad por reflujo gastroesofágico tratada con pantoprazol.

Inicia 72 horas antes de la consulta con exantema morbiliforme maculopapular diseminado que inició en los antebrazos, después afectó el tronco a nivel del abdomen, pliegues submamarios y la espalda baja. Constituido por eritema y pápulas eritematosas y algunas violáceas debajo de la mama izquierda, huellas de rascado (Figura 1). Prurito moderado. Sin síntomas generales, respiratorios, neurológicos o gastrointestinales asociados.

PCR COVID positiva, radiografía de tórax y laboratorio normal.

Se manejó con: ivermectina $6 \mathrm{mg}$ por cada $20 \mathrm{~kg}$ de peso (4 dosis), betametasona/loratadina y Aspirina Protect ${ }^{\circledR}$ una diaria. Localmente, sustituto de jabón, humectantes y mometasona tópica.

\section{Caso 2}

Mujer de 26 años originaria del Estado de México, sana, sin alergias, no tomaba medicamentos. Sin antecedentes 
de relaciones sexuales no protegidas. Había asistido a su hogar en Valle de Bravo, Estado de México cuatro días antes. Dermatosis de entre ocho y 12 horas de evolución, diseminada, con afección de tronco en cara anterior a nivel del pecho, hombros, base de cuello y abdomen, espalda en tercio inferior. Caracterizada por un exantema maculopapular de aparición súbita (Figura 2). No adenopatías retroauriculares, suboccipitales, supraclaviculares o axilares. Sin prurito. Biometría hemática $(\mathrm{BH})$ normal y VDRL negativa.

PCR para SARS-CoV-2 negativa. Biopsia: dermatitis perivascular con linfocitos y neutrófilos, eosinófilos esporádicos (Figura 3). Endotelio edematoso. Compatible con reacción a medicamentos o COVID-19.

Tratada con: ivermectina $6 \mathrm{mg}$ una cada 12 horas por dos días. betametasona/loratadina por siete días, lubricantes y mometasona tópica. El exantema remitió en 72 horas.

\section{Caso 3}

Hombre de 38 años sin comorbilidades, inicia súbitamente con exantema maculopapular generalizado. Sin síntomas generales, neurológicos, digestivos o respiratorios. Las lesiones se iniciaron en el tórax con pápulas que confluyen formando placas eritematoescamosas, pruriginosas y en algunos sitios purpúricas (Figura 4). No toma ningún medicamento. PCR negativa. Tratamiento con ivermectina/nitazoxanida, betametasona/ loratadina. Remisión del cuadro a los cinco días de tratamiento.

\section{EXANTEMA EN PLACAS Y FORMAS LOCALIZADAS DURANTE LA ENFERMEDAD}

\section{Caso 4}

Mujer de 61 años, sana en general con antecedente de herpes zóster en el mes de marzo de 2020. Durante una

Figuras 4:

Exantema maculopapular eritematopurpúrico con aspecto de pápulas perifoliculares. Afectaba tórax y extremidades.
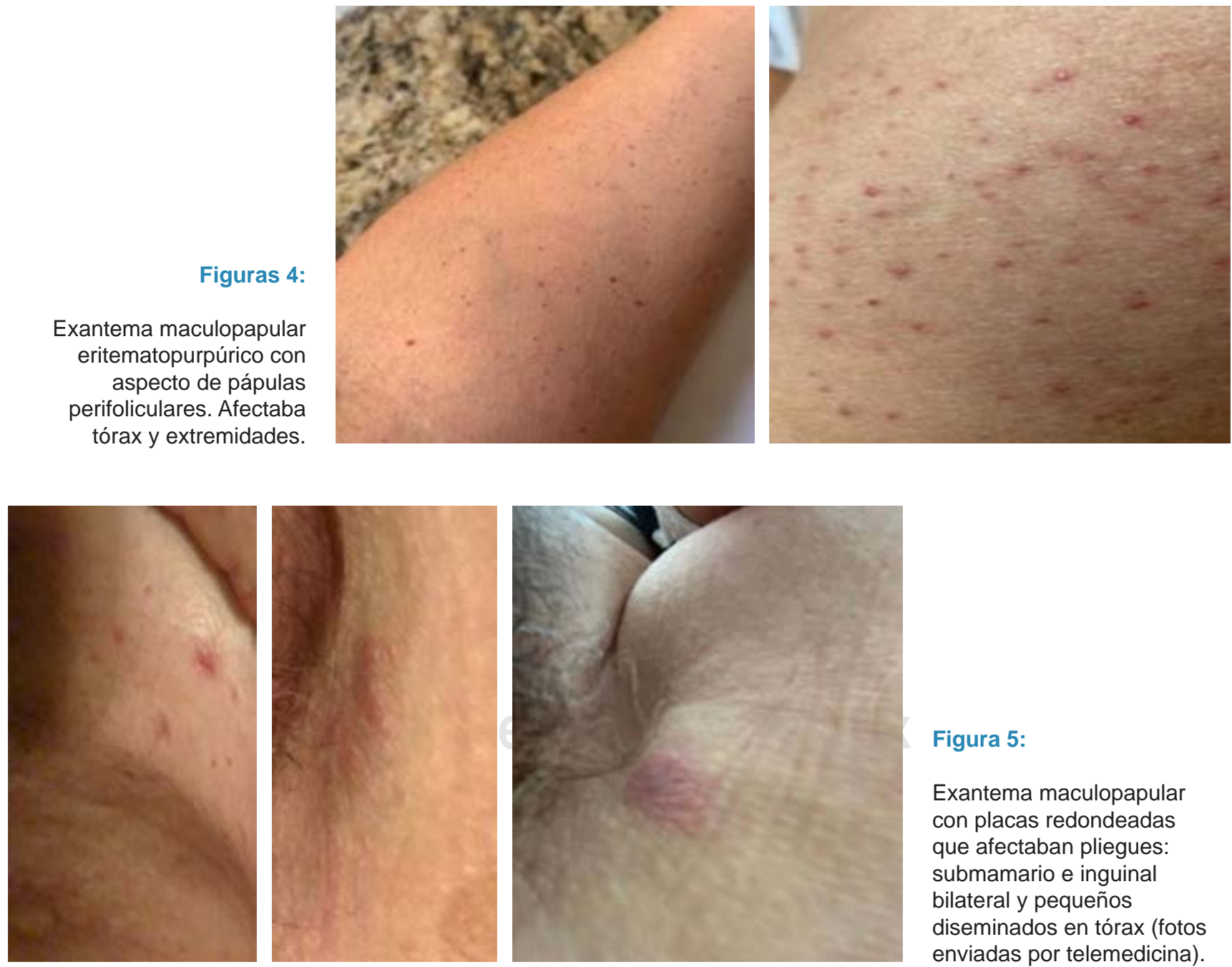

Figura 5:

Exantema maculopapular con placas redondeadas que afectaban pliegues: submamario e inguinal bilateral y pequeños diseminados en tórax (fotos enviadas por telemedicina). 
visita a sus padres tuvo contacto con un hermano que tuvo síntomas y PCR+ para SARS-CoV-2. Inicia cuatro días después con astenia y malestar general, sin fiebre ni síntomas respiratorios, neurológicos o digestivos. Cinco días después inicia con dermatosis diseminada que afectaba la cara interna de muslo e ingle derecha, otra placa en pliegue submamario izquierdo. Varias placas de aproximadamente 7-10 mm, edematosas, sin vesículas, asintomáticas. Consulta por telemedicina (Figura 5).

Se trató con ivermectina, betametasona/loratadina, lubricantes y glucocorticoides tópicos de potencia intermedia. Sin PCR.

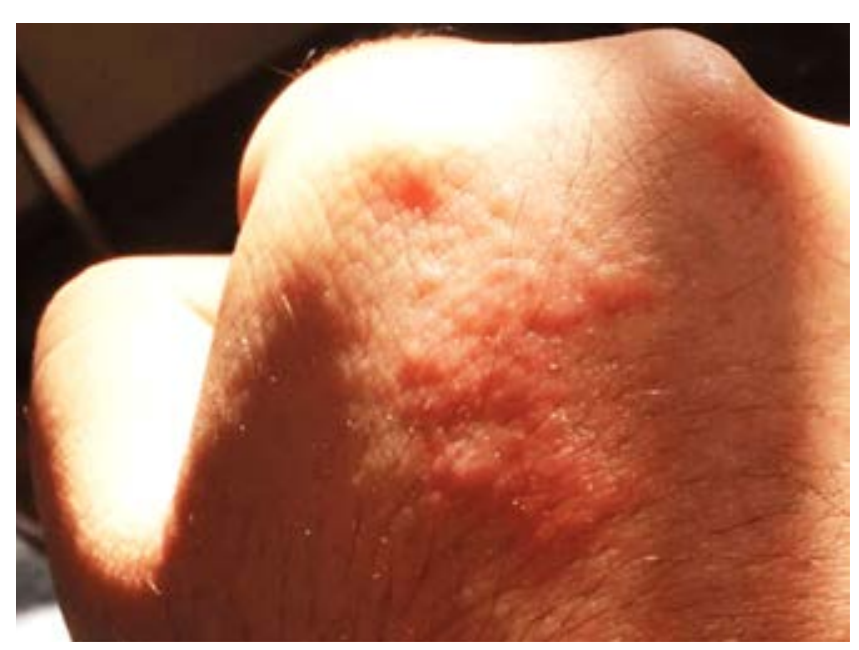

Figura 6: Placa de pápulas sobre base eritematosa (foto enviada por telemedicina).

\section{Caso 5}

Hombre de 28 años, inicia 16 de junio con fiebre y diarrea líquida que duró dos días y se autolimitó, después inicia con una mácula eritematosa de $3 \times 4.5 \mathrm{~cm}$ que se cubre de pápulas en el dorso de la mano derecha (Figura 6), asintomática. Consulta por telemedicina. PCR negativa, tres semanas después IgG anti COVID positiva.

Tratamiento con ivermectina $6 \mathrm{mg}$ cada ocho horas por un día, nitazoxanida $500 \mathrm{mg}$ cada 24 horas por seis días, mometasona tópica y sustitutos de jabón. Remisión completa.

\section{Caso 6}

Mujer de 61 años, inicia una semana antes con severa astenia y malestar general, se practicó PCR contra SARS-CoV-2 y fue positiva. Después de 15 días la astenia persistía, se agrega la presencia de pápulas eritematosas y costrosas aisladas en la espalda y en los codos. Así como caída masiva de pelo (Figura 7).

Se manejó con paracetamol, lubricantes esteroides y vigilancia estrecha.

La dermatosis remitió después de 21 días. Presentó severo efluvio telógeno.

\section{Caso 7}

Hombre de 29 años sin antecedentes relevantes para el padecimiento actual. Inicia el 15 de septiembre 2020 con faringodinia, rinorrea hialina, evacuaciones diarreicas y malestar general. A los dos días se agregan artralgias, mialgias, conjuntivitis y dolor torácico. El 18 de Septiembre aparece dermatosis que afectaba el dorso de ambas manos caracterizada por placas eritematodescamativas con pápulas foliculares

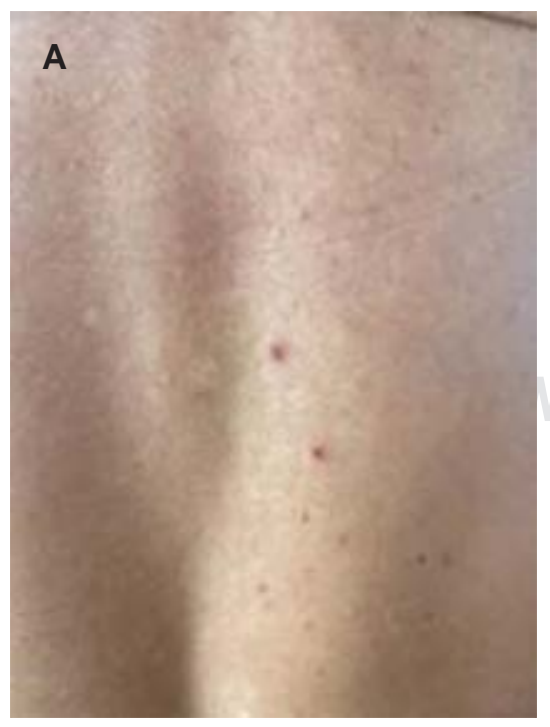

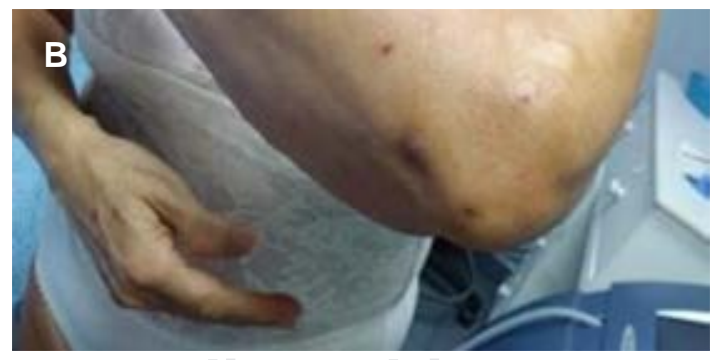

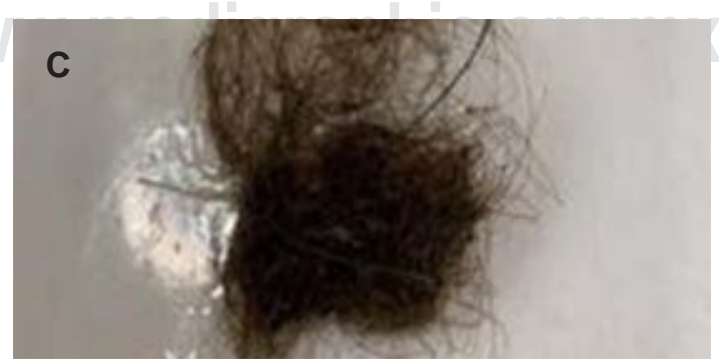

Figura 7:

A) Pápulas decapitadas en tronco y antebrazo, similares a las que se presentan en la enfermedad de Grover. B) Extremidades superiores con pápulas decapitadas. C) Efluvio telógeno. 
Figura 8:

A) Eritema maculopapular tipo placa descamativa antebrazos. B) Dorso de las manos. (Fotos enviadas por medio digital).
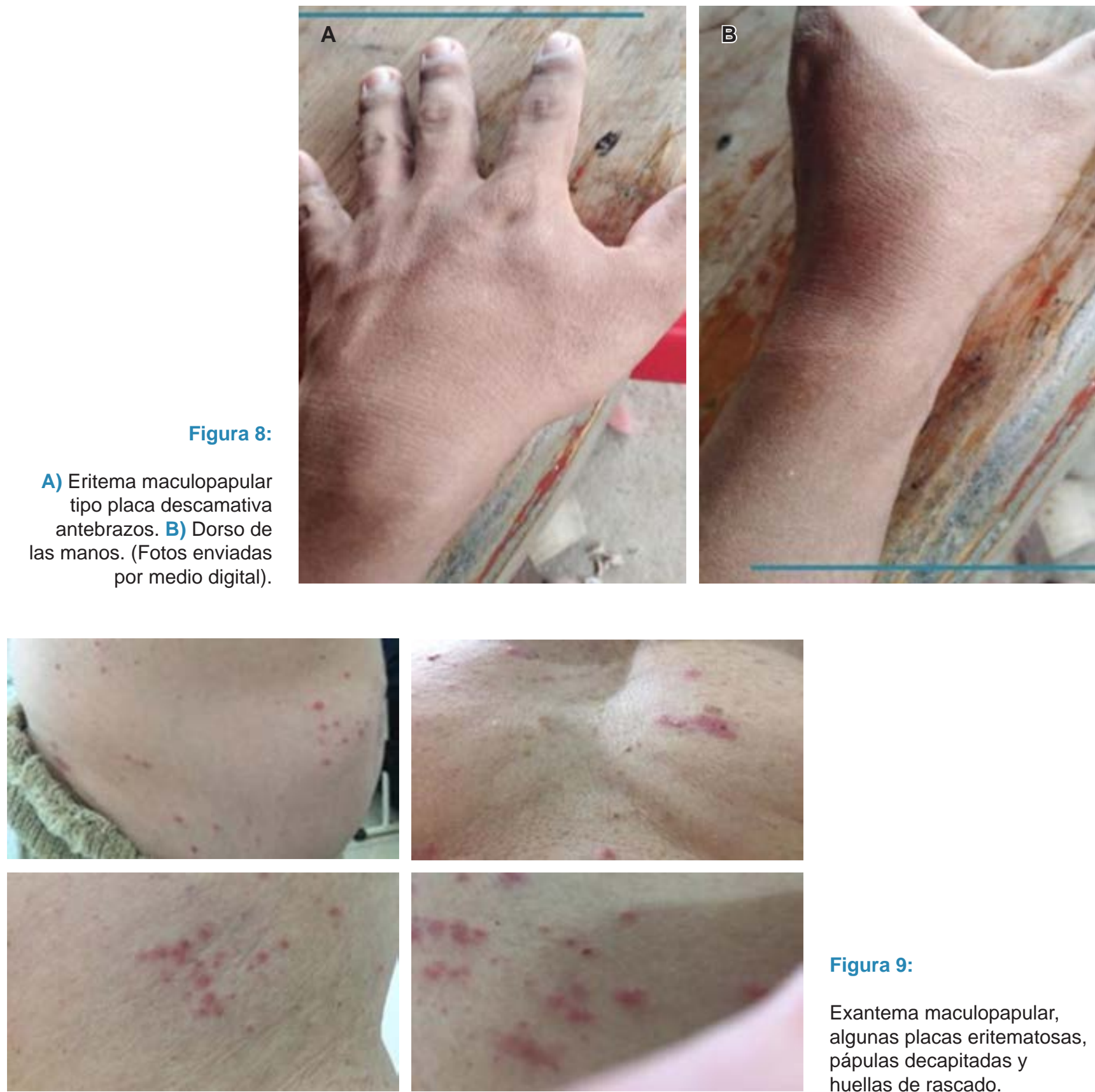

Figura 9:

Exantema maculopapular, algunas placas eritematosas, pápulas decapitadas y huellas de rascado.

(Figura 8), pruriginosas. Consulta por telemedicina, la PCR para SARS-CoV-2 es positiva. Se administra tratamiento con acetaminofén, lubricantes y esteroides de potencia intermedia.

\section{Caso 8}

Hombre de 78 años, inicia tres semanas antes de la teleconsulta con cuadros intermitentes de diarrea y estreñimiento, hipostenia e hipodinamia. Una semana más tarde aparece exantema maculopapular diseminado que afecta sobre todo el tronco, con pápulas eritematosas con tendencia a formar placas eritematoescamosas (Figura 9), prurito leve.

Las sugerencias de la teleconsulta son: efectuar PCR para SARS-CoV-2 y buscar un dermatólogo en su lugar de origen. Este facultativo le dice que no es Covid. Su hijo se muda con él y también inicia con astenia importante. En ambos la PCR contra SARS-CoV-2 es positiva. Se manejó con humectantes y antihistamínicos. 
Caso 9

Hombre de 57 años, inicia con fiebre, tos y disnea que fue progresando a la hipoxemia severa que obligó a su internamiento y consecuente intubación. A los cinco días de estancia en terapia intensiva desarrolla exantema maculopapular que afecta el tronco (Figura 10A). El paciente se encontraba recibiendo: azitromicina, anticoagulantes, lopinavir/ritonavir. También se observó cambio de coloración de las extremidades superiores a nivel de las manos con cianosis severa de los dedos y hasta tercio superior de ambas palmas (Figura 10B). Paciente trasladado a otro hospital en condiciones críticas.

\section{EXANTEMAS MACULOPAPULARES TARDÍOS}

\section{Caso 10}

Hombre de 38 años que inicia el 12 de agosto con ataque al estado general, fiebre, tos y disnea leve. Evaluado por otorrinolaringología. PCR SARS-CoV-2 positiva. Manejado con ivermectina, azitromicina, dexametasona. El cuadro respiratorio remite por completo en 10 días. Un mes después presenta exantema maculopapular, en algunas áreas urticariano que afectaba el tronco, axilas, cuello y las mejillas (Figura 11). Pápulas finas sobre eritema en grandes placas. Se inició manejo con glucocorticoides tópicos y lubricantes. El cuadro desapareció en seis días.

Figura 10:

A) Exantema maculopapular. B) Acrocianosis.
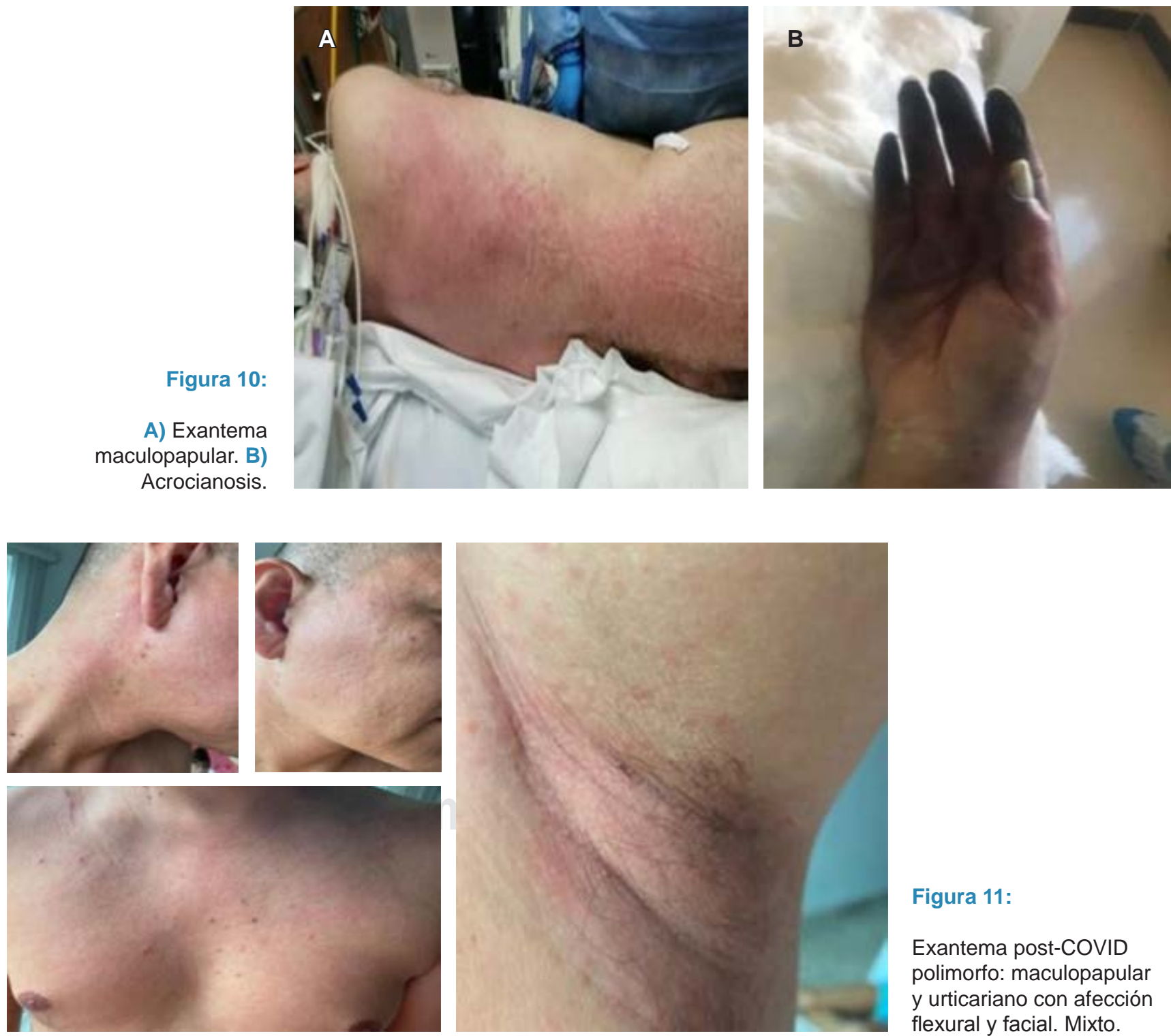

Figura 11:

Exantema post-COVID polimorfo: maculopapular y urticariano con afección flexural y facial. Mixto. 
Figura 12:

Exantema maculopapular en tórax y cuello.

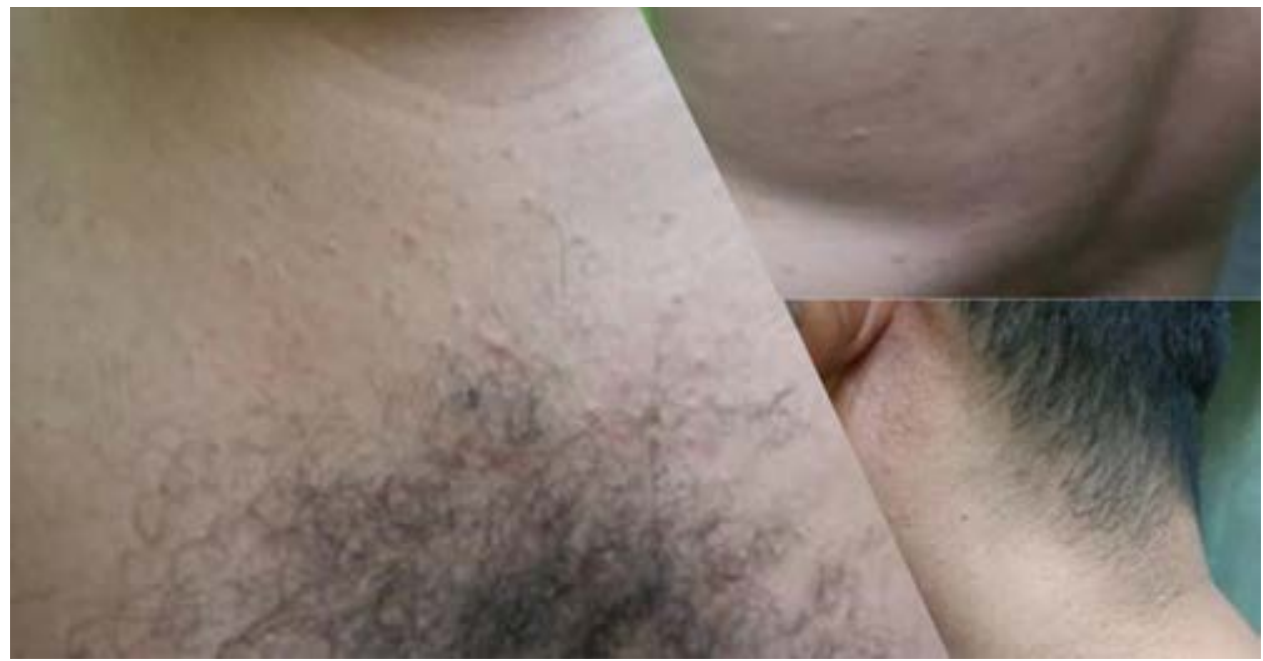

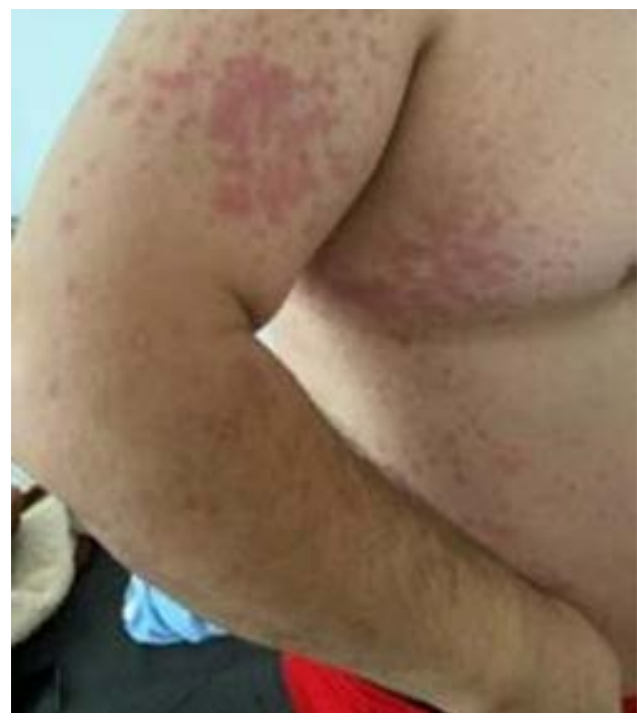

Caso 11

Hombre de 32 años, inició su padecimiento el 30 de junio de 2020 con ataque al estado general, hipertermia hasta de $38.5{ }^{\circ} \mathrm{C}$, faringodinia, rinorrea y tos. PCR SARS-CoV-2. El 16 de julio, se añade diarrea que cede en tres días. El 30 de julio inicia con dermatosis diseminada que afecta la cara, el tronco y las extremidades, compuesta por pápulas, vesículas y eritema, monomorfas (Figura 12) y pruriginosas. Tratamiento: ivermectina, azitromicina, acetaminofén.

\section{Caso 12}

Hombre de 36 años que inicia su padecimiento a finales del mes de abril 2020, con ataque al estado general, anos- mia y disgeusia. PCR positiva, el 8 de junio de 2020 inicia exantema maculopapular diseminado que afecta el tronco y las extremidades superiores e inferiores. La dermatosis se caracterizaba por exantema papular y placas pruriginosas de 6-7 mm (Figura 13). El tratamiento instaurado fue a base de lubricantes y esteroides tópicos y fexofenadina. El exantema remitió en siete días.

\section{Caso 13}

Paciente femenino de 17 años. Tres semanas antes de su consulta dermatológica inicia su padecimiento con hipertermia, ataque al estado general, mialgias y odinofagia. Se le solicitó PCR para SARS-CoV-2 a los cuatro días de sus síntomas positiva. A los 19 días de evolución inicia con 
exantema maculopapular diseminado que afectaba tronco y extremidades, caracterizado por eritema y pápulas de 3-4 mm de diámetro (Figura 14). Se inició tratamiento con emolientes y glucocorticoides tópicos durante 10 días. El exantema fue resolviendo poco a poco a los siete días de haber iniciado el tratamiento.

\section{Caso 14}

Hombre de 47 años sano que 15 días antes inicia con cefalea, fiebre, tos, disnea y ataque al estado general. Se le solicita PCR que resulta positiva para SARS-CoV-2. AI quinto día de enfermedad, la saturación baja a menos de 80, por lo que es internado para su tratamiento. En el hospital recibe glucocorticoides, azitromicina, clopidogrel y tratamiento por inhaloterapia. Dos días después de egresar del hospital, inicia exantema maculopapular que afectaba cara anterior y posterior del tronco (Figura 15), así como extremidades superiores, prurito leve, respetaba las mucosas, palmas y plantas. En este momento sólo tomaba vitaminas. Se diagnostica un exantema maculopapular post-COVID. El paciente se negó a que se le hiciera una biopsia. Se trató con sustitutos de jabón, lubricantes, glucocorticoides tópicos y sistémicos, con lo que el exantema remitió en cinco días.

\section{DISCUSIÓN}

Los exantemas eritematosos (morbiliformes), maculopapulares, pitiriasis rosada like y eritema polimorfo like han sido clasificados por diversos autores de una forma muy confusa. A pesar de ello, los exantemas de este tipo
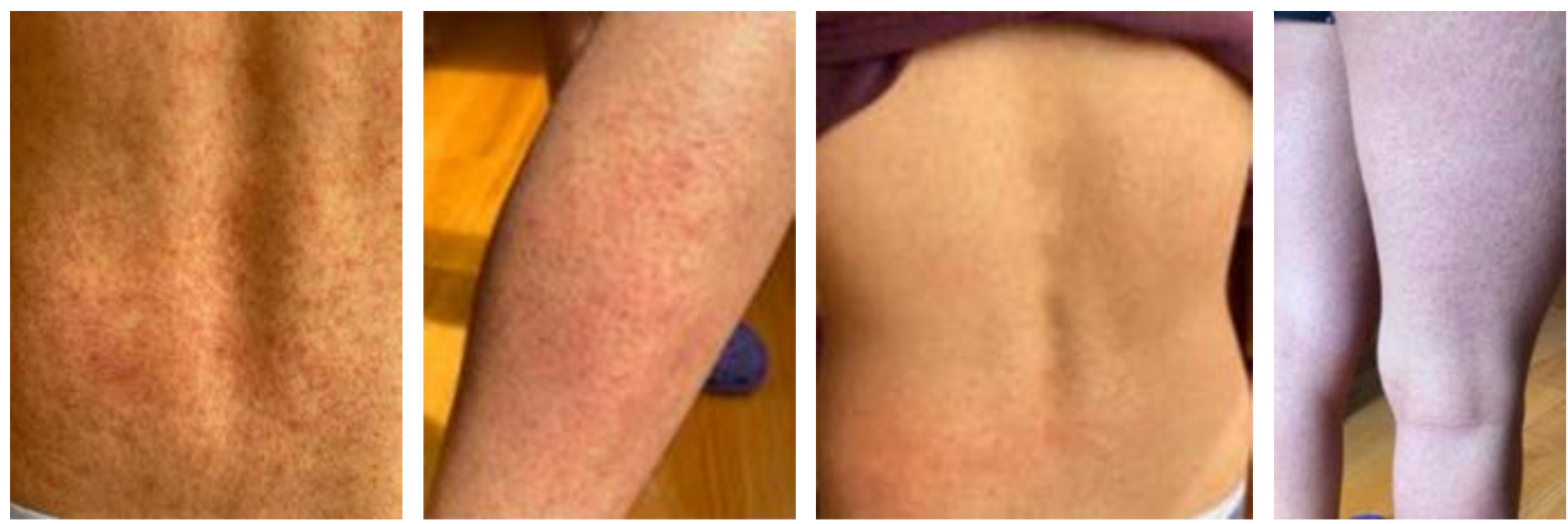

Figura 14: Exantema maculopapular generalizado.

Figura 15:

Exantema maculopapular eritematoso y confluente.
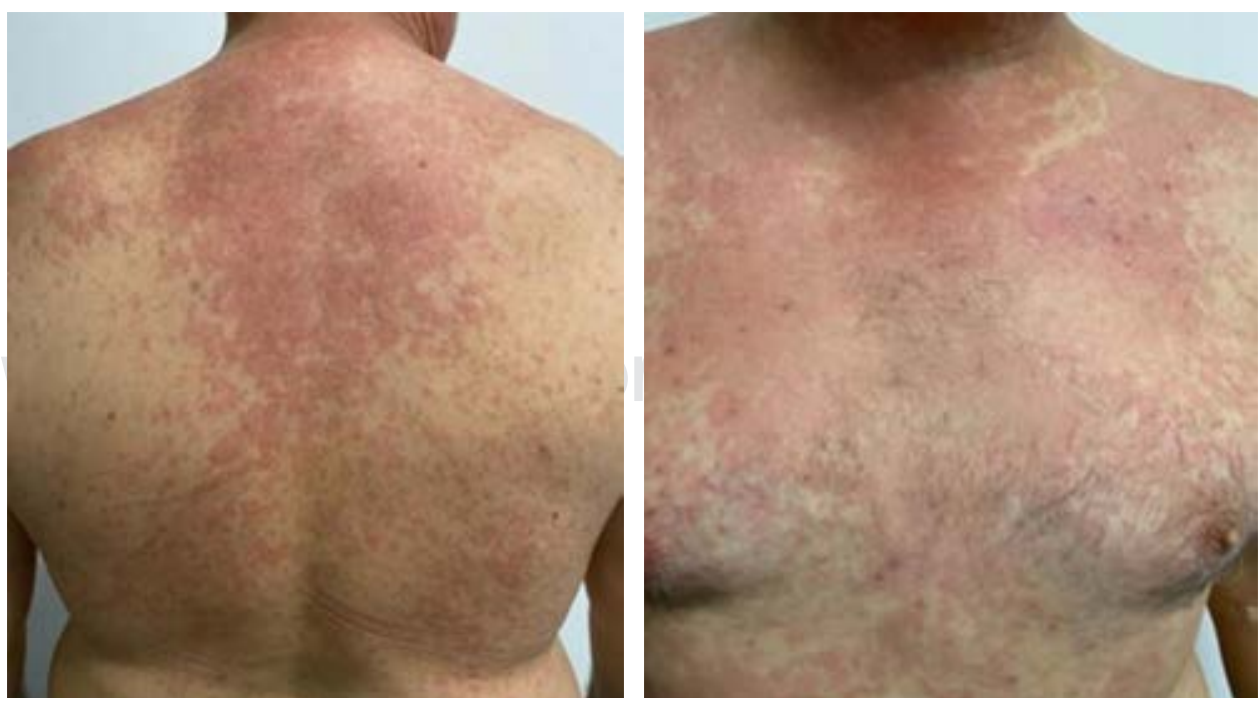
representan la manifestación cutánea de COVID más frecuente en el ámbito mundial. También en nuestra experiencia la erupción maculopapular es la más frecuente (48.4\%). La morfología del exantema puede variar, puede empezar con pequeñas pápulas, evolucionar a grandes placas inflamatorias confluentes y diseminadas, algunas con morfología en "blanco de tiro". Nuestros casos tienen todo tipo de morfologías, las más complicadas y polimorfas son las tardías.

Pueden aparecer previas a la presentación de síntomas sistémicos, simultáneamente a ellos y en forma tardía (hasta 60 días después). Parece ser que la activación de algunos virus como HHV, EBV y los múltiples medicamentos que reciben favorecen la presentación de estos cuadros. ${ }^{1-7}$

En nuestro medio, podemos estudiar la asociación con activación del EBV; sin embargo, no la sospechamos. No tenemos aún la posibilidad de detectar infección por herpes 6 y 7 ni por serología ni por inmunohistoquímica.

La PCR puede tener hasta $50 \%$ de falsas negativas y las biopsias muestran cuadros característicos de enfermedad endotelial inflamatoria por linfocitos, neutrófilos y ocasionalmente eosinófilos. Habitualmente responden a glucocorticoides tópicos y sistémicos.

Es de capital importancia recordar que la población se sigue moviendo y no respeta el confinamiento; es necesario hacer preguntas importantes sobre viajes a zonas boscosas o tropicales, relaciones sexuales no protegidas o con diversas parejas (homo o heterosexuales), ingesta de medicamentos por otras razones. Aunque debamos primero descartar COVID-19, no podemos olvidar que existen casos similares por otros virus, bacterias, parásitos, reacciones autoinmunes y medicamentos. ${ }^{7-9}$

Más de $50 \%$ de nuestros casos fueron vistos por teleconsulta, eso impidió que se estudiaran con profundidad.

\section{REFERENCIAS}

1. Li H, Zhao Y, Zhou L, Hu J. Cutaneous, skin histopathological manifestations and relationship to COVID-19 infection patients. Dermatol Ther. 2020; 33 (6): e14157. doi: 10.1111/dth.14157.

2. Guan WJ, Ni ZY, Hu Y, Liang WH, Ou CQ, He JX et al. Clinical characteristics of coronavirus disease 2019 in China. N Engl J Med. 2020; 382 (18): 1708-1720.

3. Catala A, Galván-Casas C, Carretero-Hernández G, RodríguezJiménez P, Fernández-Nieto D, Rodríguez-Villa A et al. Maculopapular eruptions associated to COVID-19: A subanalysis of the COVIDPiel study. Dermatol Ther. 2020; 33 (6): e14170. doi: 10.1111/ dth. 14170 .

4. Gianotti R, Recalcati S, Fantini F, Riva C, Milani M, Dainese E et al. Histopathological study of a broad spectrum of skin dermatoses in patients affected or highly suspected of infection by COVID-19 in the northern part of Italy: analysis of the many faces of the viralinduced skin diseases in previous and new reported cases. Am J Dermatopathol. 2020; 42 (8): 564-570.

5. Gisondi P, Plaserico S, Bordin C, Alaibac M, Girolomoni G, Naldi L. Cutaneous manifestations of SARS-CoV-2 infection: a clinical update. J Eur Acad Dermatol Venereol. 2020; 34 (11): 2499-2504. doi: $10.1111 /$ jdv. 16774 .

6. Sachdeva M, Gianotti R, Shah M, Bradanini L, Tosi D, Veraldi S et al. Cutaneous manifestations of COVID-19: report of three cases and a review of literature. J Dermatol Sci. 2020; 98 (2): 75-81. doi: 10.1016/j.jdermsci.2020.04.011.

7. Drago F, Ciccarese G, Gasparini G, Cogorno L, Javor S, Toniolo A et al. Contemporary infectious exanthems: an update. Future Microbiol. 2017; 12: 171-193. doi: 10.2217/fmb-2016-0147.

8. Muzumdar S, Rothe MJ, Grant-Kels JM. The rash with maculopapules and fever in adults. Clin Dermatol. 2019; 37 (2): 109-118.

9. Tang K, Wang Y, Zhang H, Zheng Q, Fang R, Sun Q. Cutaneous manifestations of the Coronavirus Disease 2019 (COVID-19): a brief review. Dermatol Ther. 2020; 33 (4): e13528. doi: 10.1111/ dth.13528.

Conflicto de intereses: Los autores manifiestan no tener ningún conflicto de intereses. 